\title{
(Ir)retroactividad de las modificaciones a la norma complementaria de una Ley Penal en Blanco*
}

\author{
Raúl A. Baldomino Díaz \\ Abogado y Magíster en Economía y Gestión, Universidad Gabriela Mistral \\ Magíster en Derecho Penal, Universidad de Talca \\ rbaldomino@pjud.cl
}

\section{Resumen}

El autor, a partir del nullum crimen nulla poena sine lege, expone los alcances del principio de legalidad en las leyes penales en blanco, indicando que aquellas deben contener el verbo rector de la conducta y su faz subjetiva, permitiendo su complemento por las normas reglamentarias.

Reconociendo a la seguridad jurídica como fundamento de la irretroactividad de la ley penal, y a la proporcionalidad y necesidad de la pena como justificación de la retroactividad de la ley penal más benigna, expone los problemas de aplicación retroactiva que pueden aparecer con la modificación de la norma complementaria.

Palabras clave: Tipo penal en blanco, retroactividad, irretroactividad, norma complementaria, seguridad jurídica, proporcionalidad y necesidad de pena.

\begin{abstract}
The author, starting from the nullum crimen nulla poena sine lege principle, explains the scope of the legality principle for criminal laws in blank, stating that they must contain the main verb of the conduct and its subjective aspect, thus allowing their completion through statutory norms.

Recognizing legal certainty as the basis for irretroactivity of criminal laws, and proportionality and necessity of punishment as a justification for more benign criminal law retroactivity, shows the underlying retroactive application problems of amending the statutory norm.
\end{abstract}

Key words: In blank criminal type, retroactivity, irretroactivity, statutory norms, legal certainty, proportionality and necessity of punishment.

\section{Introducción}

De la lectura de la Constitución Política de la República, de 1980, se aprecia, en Chile, la vigencia del principio de irretroactividad de la ley penal, con la sola excepción de la ley

\footnotetext{
* Tesina expuesta para la obtención del grado académico de Magíster en Derecho Penal, dirigida por el Dr. Jean Pierre Matus Acuña, a quien debo mi agradecimiento por su orientación y consejos. Se han incorporado, también, las valiosas observaciones de la comisión examinadora.
} 
penal posterior más favorable. Pero, ¿qué sucede si se modifica la norma complementaria del tipo penal?, ¿puede haber efecto retroactivo si lo que se modifica no es el texto del tipo legal ni la ilicitud del hecho, que permanece intacto?

Sólo determinando los presupuestos ya indicados, será posible, en un posterior estudio, establecer la admisibilidad de errores sobre el supuesto de hecho del precepto penal, o sobre la existencia o límites de dicha norma no penal, o, en otras palabras, en qué casos puede ocurrir un error de tipo o un error de prohibición en estos delitos penales en blanco.

\section{Tipo penal en blanco.}

\subsection{Concepto.}

Las leyes que contienen tipos penales en blanco se caracterizan porque indican la sanción, pero no describen completa y detalladamente a su supuesto de hecho, las conductas prohibidas (u ordenadas, en los delitos de omisión), ${ }^{1}$ remitiéndose para su complemento a otra norma jurídica, a otras leyes penales, a leyes de otros sectores del ordenamiento jurídico o a disposiciones de rango inferior a la ley (generalmente de carácter reglamentario), ${ }^{2}$ la cual pasa a formar parte del tipo penal. ${ }^{3}$

En el contexto de un Derecho Penal de tipos, como es el nuestro, la regulación, admisibilidad y límites de los tipos penales en blanco sólo es posible respetando el nullum crimen nulla poena sine lege. Existe consenso en que su utilización sólo es aceptable cuando sea necesaria por razones de técnica legislativa, por el carácter extraordinariamente cambiante, flexible o complejo de la materia objeto de la regulación, por la evolución social y económica de la sociedad, que - de lo contrario - exigiría para su adaptación una revisión muy frecuente de las acciones prohibidas u ordenadas por la ley, admitiendo que el ámbito concreto que se sanciona sea determinado por normas extrapenales de complemento. ${ }^{4}$ Ello explica el porqué de su utilización, sobre todo, en el área penal-económica.

\footnotetext{
${ }^{1}$ CURY URZÚA, Enrique, La ley penal en blanco, Bogotá: ed. Temis S.A., 1988, p. 24. ETCHEBERRY, Alfredo, Derecho Penal, parte general, t. I, Santiago: Editorial Jurídica de Chile, $3^{\text {a }}$ ed., 1998, p. 83, lo denomina "presupuesto de hecho" o "descripción de una hipótesis de hecho". MIR PUIG, Santiago, Derecho Penal, parte general. Montevideo/Buenos Aires: ed. BdeF, $7^{\text {a }}$ ed., 2005, p. 74, habla de "supuesto de hecho" y "consecuencia jurídica", lo mismo YÁÑEZ PÉREZ, Sergio, "Las leyes penales en blanco", Gaceta Jurídica, $\mathrm{N}^{\circ} 58$ (1985), p. 2, y LUZÓN PEÑA, Diego, Curso de Derecho Penal, parte general, Madrid: ed. Universitas, 2002, p. 143.

${ }^{2}$ Por todos, CURY, La ley penal en blanco, cit. nota $\mathrm{n}^{\circ} 1 ; \mathrm{y}$, SANTANA VEGA, Dulce María, El concepto de ley penal en blanco, Buenos Aires: ed. Ad-Hoc S.R.L., 2000.

${ }^{3}$ SANTANA VEGA, El concepto, cit. nota ${ }^{\circ}$ 2, p. 27. SILVA SÁNCHEZ, Jesús María, "Las "normas de complemento' de las leyes penales en blanco pueden emanar de las Comunidades Autónomas", Revista del Poder Judicial, $4^{\mathrm{a}}$ época, $\mathrm{N}^{\circ} 52$ (1998), p. 489.

${ }^{4}$ BUSTOS RAMÍREZ, Juan, Obras Completas, Derecho Penal, parte general, t. I, Santiago: ed. Jurídica de Santiago, 2007, p. 387. CURY URZÚA, Enrique, Derecho Penal, parte general, Santiago: ed. Universidad Católica de Chile, $7^{\mathrm{a}}$ ed., 2005, p. 175. LUZÓN PEÑA, Curso, cit. nota $\mathrm{n}^{\mathrm{o}} 1$, p. 151. CASSOLA PERENZUTTI, Gustavo, Medio ambiente y Derecho Penal, Montevideo-Buenos Aires: ed. BdeF, 2005, p. 29.
} 
Atendido el concepto que hemos dado, se suele distinguir entre dos modalidades de tipos penales en blanco: ${ }^{5}$ Tipos Penales en Blanco Propios, que son aquellos en que el texto legal determina la sanción, pero para la descripción del hecho punible se complementa con remisiones a normas jurídicas de rango inferior a una ley; ${ }^{6} \mathrm{y}$, Tipos Penales en Blanco Impropios, que son aquellos cuyo complemento del núcleo central de la conducta es otra disposición contenida en la misma ley (reenvío interno), ${ }^{7}$ o en otra ley (reenvío externo). ${ }^{8}$

En los tipos en blanco impropios, dado que la norma complementaria es otra ley, se aplica directamente el principio de irretroactividad del tipo penal, con la sola excepción de la ley penal más favorable. Ello, sin perjuicio de los cuidados que debe tenerse frente a la falta o deficiente taxatividad que presentan, normalmente, las normas legales no penales. ${ }^{9}$ Por lo anterior, en mi opinión, no pueden ser considerados leyes penales en blanco propiamente tales, sino tan sólo normas incompletas con una cuestionable técnica legislativa. ${ }^{10}$

\subsection{Requisitos de validez de los tipos penales en blanco propios.}

\subsubsection{Constitucionalidad de los tipos penales en blanco.}

Los tipos penales en blanco plantean problemas desde el punto de vista del principio de legalidad, por afectar al mandato de determinación, cuando para la descripción de las conductas sancionadas se hace remisión a disposiciones jurídicas de rango inferior a la ley. Por ello, en la doctrina extranjera existen dudas de su constitucionalidad. ${ }^{11}$

\footnotetext{
5 Por todos, YÁÑEZ PÉREZ, "Las leyes penales en blanco", cit. nota no 1, p. 2. MIR PUIG, Santiago, Introducción a las bases del derecho penal, Montevideo/Buenos Aires: ed. BdeF, 2ª ed., 2003, pp. 37 y 38.

${ }^{6}$ Por todos, POLITOFF, Sergio; MATUS, Jean Pierre; RAMÍREZ, María Cecilia, Lecciones de Derecho Penal Chileno, parte general, Santiago: Editorial Jurídica de Chile, $2^{\text {a }}$ ed., 2004, p. 96. TIEDEMANN, Klaus, "La ley penal en blanco: concepto y cuestiones conexas", trad. LLABRÉS FUSTER, Antoni, en: EL MISMO, Temas de Derecho Penal Económico y Ambiental, Lima: ed. Idemsa, 1999, pp. 68 y 69.

${ }^{7}$ CURY, La ley penal en blanco, cit. nota $\mathrm{n}^{\circ} 1$, p. 39, para quien si bien respetan el nullum crimen nulla poena sine lege praevia et scripta, no respetaría el sine lege stricta, lo que haría inútil el respeto de las otras dos limitaciones.

${ }^{8}$ SANTANA VEGA, El concepto, cit. nota no 2 , pp. 31, 32 y 36, asumiendo la concepción amplia estima que se trata de leyes penales en blanco. RODRÍGUEZ COLLAO, Luis, "Constitucionalidad de las leyes penales en blanco", Revista de Derecho de la Universidad Católica de Valparaíso, VIII (1984), p. 233. ETCHEBERRY, Derecho Penal (parte general), cit. nota n ${ }^{\circ} 1$, p. 85 y 86.

${ }^{9}$ CURY, Derecho Penal (parte general), cit. nota ${ }^{\circ} 4$, p. 176, advierte que afectan el principio de reserva, pues no son precisos los límites para el intérprete. MUÑOZ CONDE, Francisco, Introducción al Derecho Penal, Montevideo/Buenos Aires: ed. BdeF, 2007, pp. 59 a 62.

${ }^{10}$ NOVOA MONREAL, Eduardo, Curso de Derecho Penal Chileno, Santiago: Editorial Jurídica de Chile, 1966, pp. 120 y 121. MESTRE DELGADO, Esteban, "Límites constitucionales de las remisiones normativas en materia penal", Anuario de Derecho Penal y Ciencias Penales, t. XLI, fascículo II, (1998), p. 507, nota $\mathrm{n}^{\circ}$ 14. JIMÉNEZ DE ASÚA, Luis, Principios de Derecho Penal. La ley y el delito, Buenos Aires: AbeledoPerrot, ed. Sudamericanas, 1990, p. 96.

${ }^{11}$ Por todos, MUÑOZ CONDE, Francisco; GARCÍA ARÁN, Mercedes, Derecho Penal, parte general, Valencia: ed. Tirant Lo Blanch, $7^{\mathrm{a}}$ ed., 2002, p. 112, para quienes si el tipo exige una infracción reglamentaria, tan esencial es aquella, como el resto de los elementos de la descripción típica. En Chile, Sentencia Corte Suprema (en adelante, SCS), de 28-01-1986, I.C. N ${ }^{\circ} 24.810$, Gaceta Jurídica, N 69 (1986), pp. 34 a 42, voto disidente del ministro Rafael Retamal, para quien la exigencia de describirlo significaría que la ley debe bastarse a sí misma en la configuración del hecho punible.
} 
El principio de legalidad, en materia penal, ${ }^{12}$ limita la forma en que el Estado ejerce el ius puniendi, pues sólo puede hacerlo si una ley anterior a la ejecución de un hecho lo describe como delito y establece, además, cual es la pena que debe aplicarse a quien lo realiza, nullum crimen sine lege, nulla poena sine lege. Nuestra Carta Fundamental lo consagra como parte del proceso de constitucionalización del Derecho Penal, ${ }^{13}$ adquiriendo contenido material normativo como institución propia de un Estado Democrático de Derecho. ${ }^{14}$

En efecto, el principio de legalidad no debe ser considerado como una mera restricción formal, sino que es una inferencia lógica de las funciones de motivación y de advertencia que la tipificación de conductas y penas tiene en los integrantes de la sociedad, pero sobre todo en la función garantizadora de la tipicidad, la cual exige que la instauración de delitos y penas sea consecuencia de un acuerdo del órgano del Estado más representativo del interés social, y no que responda al mero arbitrio de la autoridad. ${ }^{15}$ La ley sólo puede regular y aplicarse a hechos acaecidos a partir y durante su período de vigencia, tempus regit actum. Para conseguir este objetivo limitador, la ley debe ser escrita, previa, cierta y estricta. $^{16}$

Si la inconstitucionalidad de las leyes penales en blanco se debe a la afectación del mandato de determinación, significa que se infringe el principio de legalidad, en sus exigencias de ley escrita, cierta y estricta.

\section{a) Lex Scripta (prohibición de derecho reglamentario y consuetudinario).}

De acuerdo con el artículo $19 \mathrm{~N}^{\mathrm{o}} 3$, inciso 8, de nuestra Constitución Política y con los artículos 1 y 18 del Código Penal (en adelante, C.P.), delitos y penas sólo se pueden crear, modificar y derogar por Ley, dictada con las formalidades y procedimientos establecidos en la Constitución, porque su creador es el órgano del Estado más representativo de la pluralidad de pensamientos al interior de una sociedad organizada como un Estado Democrático de Derecho. Esto se conoce como el "principio de reserva" ${ }^{17}$

\footnotetext{
${ }^{12}$ Por todos, ETCHEBERRY, Derecho Penal (parte general), cit. nota $\mathrm{n}^{\mathrm{o}} 4$, pp. 75 y ss.

${ }^{13}$ Por todos, GUZMÁN DÁLBORA, José Luis, "Relaciones del derecho penal con el derecho constitucional, y su concreción en la Constitución Política Chilena (1980)", Anuario de Filosofía Jurídica y Social, $\mathrm{N}^{\circ} 12$ (1994), pp. 174 y ss.

${ }^{14}$ CURY, La ley penal en blanco, cit. nota $n^{\circ} 1$, pp. 11 y ss. En una línea similar, ETCHEBERRY, Derecho Penal (parte general), cit. nota $\mathrm{n}^{\circ} 4$, p. 78, para quien “es algo más que una institución puramente jurídica: es en realidad la base de todo un sistema político que considera la libertad individual como el más elevado valor social.". JIMÉNEZ DE ASÚA, Principios, cit. nota n 10, pp. 96 a 99. MUÑOZ CONDE; GARCÍA ARÁN, Derecho Penal (parte general), cit. nota $n^{\circ} 11$, pp. 97 y ss. SILVA SÁNCHEZ, Jesús María, Aproximación al Derecho Penal Contemporáneo, Barcelona: ed. Bosch, 2002, pp. 253 y 257, habla de "principio de legitimación democrática de las intervenciones jurídico-penales”. LASCURAÍN SÁNCHEZ, Juan Antonio, Sobre la retroactividad penal favorable, Madrid: ed. Civitas, 2000, p. 23.

${ }^{15}$ GARCÍA CAVERO, Percy, Derecho Penal Económico, parte general, t. I, Lima: ed. Jurídicas Grijley, $2^{\mathrm{a}}$ ed., 2007, pp. 131 y 132.

${ }^{16}$ Por todos, ROXIN, Claus, Derecho Penal, parte general, t. I. Fundamentos. La estructura de la teoría del delito, Trad. LUZÓN PEÑA, Diego-Manuel; DÍAZ Y GARCÍA CONLLEDO, Miguel; de VICENTE REMESAL, Javier, Madrid: Civitas ediciones, 2006, pp. 137 y ss.

${ }^{17}$ MESTRE DELGADO, "Límites constitucionales", cit. nota no 10, p. 510.
} 
Lex Certa (prohibición de conductas y penas indeterminadas).

Según la Constitución, no hay delito "sin que la conducta que se sanciona esté expresamente descrita en" la ley. No basta con que un acto sea signado como delito, debe describirse claramente la conducta prohibida, al menos en lo sustancial, y, además, determinarse la pena que se le aplicará. ${ }^{18}$ Este mandato constitucional informa un límite a la posible arbitrariedad del legislador, porque para castigar una conducta debe describirla con claridad y exactitud, al menos en sus rasgos o presupuestos generales, evitando las llamadas "cláusulas generales" en las leyes, que si son muy indeterminadas o vagas permiten abarcar cualquier conducta en el tipo penal, lo que priva de contenido material al principio de legalidad y atenta contra la seguridad jurídica; ${ }^{19}$ y limita, también, a los jueces, como el presupuesto básico del principio sine lege stricta, ${ }^{20}$ el cual carece de importancia si el legislador entrega normas de contenido difuso, dejando vacía de contenido la prohibición de analogía para los jueces. ${ }^{21}$

El "mandato de determinación" se vincula con el tipo, toda vez que al legislador le corresponde identificar y describir los elementos objetivos y subjetivos que lo componen. El principio de "tipicidad", que deviene de la aplicación del principio de legalidad y del principio de responsabilidad por el hecho, es un elemento más de aquel mandato. ${ }^{22}$

La exigencia de certeza surge de la función de motivación de la norma penal respecto del ciudadano, ${ }^{23}$ y constituye una garantía de seguridad jurídica para aquel, pues, sólo así, éste podrá aprehender el contenido normativo esencial de la norma penal, saber qué es lo que está prohibido penalmente y qué es lo que puede hacer (ámbito de lo permitido), y adecuar su comportamiento o no conforme a ello. ${ }^{24}$

c) Lex Stricta (prohibición de analogía y de interpretación extensiva).

${ }^{18}$ CURY, La ley penal en blanco, cit. nota $n^{\circ}$ 1, p. 15. JAÉN VALLEJO, Manuel, Cuestiones actuales del Derecho Penal económico, Buenos Aires: ed. Ad-Hoc, 2004, p. 34.

${ }^{19}$ Por todos, MUÑOZ CONDE/GARCÍA ARÁN, Derecho Penal (parte general), cit. nota no 11 , p. 103. SILVA SÁNCHEZ, Aproximación, cit. nota nº 14, p. 255.

${ }^{20}$ ROXIN, Derecho Penal (parte general), cit. nota no 16, p. 137 y ss. JAKOBS, Günther, Derecho Penal, parte general. Fundamentos y teoría de la imputación. Trad. CUELLO CONTRERAS, Joaquín; SERRANO GONZÁLEZ DE MURILLO, José Luis, Madrid: Marcial Pons, ediciones jurídicas, 2ª ed. corregida, 1997, p. 95.

${ }^{21}$ FERNÁNDEZ CRUZ, José Ángel, "La naturaleza y contenido del mandato de Lex Certa en la doctrina del Tribunal Constitucional Español”, Revista de Derecho, 'Derecho y Medioambiente', número especial (1998), pp. 147 y ss. YÁÑEZ PÉREZ, "Las leyes penales en blanco”, cit. nota nº 1, p. 10.

${ }^{22}$ Sentencia Tribunal Constitucional (en adelante, STC), de 26-08-1996, causa rol N 244: "es necesario destacar los principios de legalidad y de tipicidad, los cuales no se identifican, sino que el segundo tiene un contenido propio como modo de realización del primero. La legalidad se cumple con la previsión de los delitos e infracciones y de las sanciones en la ley, pero la tipicidad requiere de algo mas, que es la precisa definición de la conducta que la ley considera reprochable, garantizándose así el principio constitucional de seguridad jurídica y haciendo realidad, junto a la exigencia de una ley previa, la de una ley cierta.".

${ }^{23}$ SILVA SÁNCHEZ, Aproximación, cit. nota no 14, p. 353, nota 191.

${ }^{24}$ ARROYO ZAPATERO, Luis, "Principio de legalidad y reserva de ley en materia penal", Revista Española de Derecho Constitucional, año 3, No 8 (1983), p. 16, afirma que es la función de motivación de la norma penal, como fundamento político criminal, el que permite explicar la irretroactividad de las normas sancionadoras y la retroactividad de las normas favorables. 
Los jueces sólo pueden imponer castigos a aquellas conductas que puedan subsumirse en la descripción típica, ${ }^{25}$ rechazándose la aplicación de la integración analógica y de la interpretación extensiva para llenar las lagunas de la ley, por constituir la imposición de una sanción a una conducta no prevista como delito por la ley. ${ }^{26} \mathrm{Al}$ momento de interpretar y aplicar la ley penal, los jueces deben regirse exclusivamente por los elementos ya descritos por el legislador, no excediendo de su interpretación teleológica, como derivación del principio de certeza en el cumplimiento irrestricto y escrupuloso del texto legal. ${ }^{27}$

\subsubsection{Presupuestos de su validez constitucional.}

En Chile, la discusión sobre su constitucionalidad ha sido en buena manera aclarada desde la aprobación de la Constitución Política de 1980, en que expresamente se indicó que la ley debe señalar la descripción de la conducta, pero no se exigió que esta determinación fuera completa, permitiendo la existencia y validez de las leyes penales en blanco, así lo sostienen doctrina $^{28}$ y jurisprudencia mayoritarias. ${ }^{29}$

En Chile, sí existe controversia en cuanto a los alcances de este tipo de leyes; así, hay quien sostiene que los ciudadanos están obligados a conocer la ley, pero no existe tal obligación respecto de las normas administrativas, por lo que crean incertidumbre, aumentada por el riesgo que las normas complementarias se deroguen, modifiquen o no se dicten. ${ }^{30}$

Otros autores, en cambio, sostienen que lo importante es que el tipo penal se complete, dando con ello cumplimiento al requisito de lex certa et stricta (pilar fundamental de la tipicidad), sin importar cuál sea la norma jurídica que lo logre y su rango; ${ }^{31}$ al punto de afirmar que si la esencia de la acción o verbo rector se encuentra descrito en la propia ley, es una ley parcialmente en blanco; en cambio, si la descripción legal carece de determinación y queda sujeta a la norma administrativa, se trata de una ley totalmente en blanco, siendo estas últimas inconstitucionales. ${ }^{32}$ Todas estas opiniones no establecen

\footnotetext{
${ }^{25}$ Por todos, ETCHEBERRY, Derecho Penal (parte general), cit. nota $\mathrm{n}^{\circ} 4$, p. 76.

${ }^{26}$ STC, de 30-03-2007, rol No 549: "Dicha disposición consagra el principio de legalidad en su manifestación de tipicidad o taxatividad. Su aplicación requiere que el legislador formule las normas penales de manera precisa y determinada, excluyendo la analogía.".

${ }^{27}$ FERNÁNDEZ CRUZ, "La naturaleza y contenido del mandato de Lex Certa", cit. nota no 21, pp. 142 y 143. ROXIN, Derecho Penal (parte general), cit. nota n ${ }^{\circ}$ 16, p. 149.

${ }^{28}$ Actas oficiales de la Comisión de Estudios de la Nueva Constitución, sesión 399, de 12-07-1978, pp. 3149 a 3152. CURY, La Ley penal en blanco, cit. nota $\mathrm{n}^{\circ} 1$, pp. 68 y ss. YÁÑEZ PÉREZ, "Las leyes penales en blanco", cit. nota ${ }^{\circ} 1$, pp. 6 a 9. ETCHEBERRY, Derecho Penal (parte general), cit. nota $\mathrm{n}^{\circ}$ 4, p. 86. RODRÍGUEZ COLLAO, "Constitucionalidad", cit. nota no 6, pp. 240 y 241. EVANS DE LA CUADRA, Enrique, Los Derechos Constitucionales, t. II, Santiago: Editorial Jurídica de Chile, $3^{\mathrm{a}}$ ed., 2004, pp. 150, 151, 157 y 158.

${ }^{29}$ SCS, de 16-07-2002, I.C. 4790-2002: "lo que se incorporó al precepto constitucional es el llamado principio de tipicidad y, por lo mismo, no consagra una prohibición a la existencia de leyes penales en blanco". STC, de 09-11-2006, rol No 468. STC, de 27-09-2007, rol No 781.

${ }^{30}$ COUSIÑO, Luis, Derecho Penal Chileno, parte general, t. I, Santiago: Editorial Jurídica de Chile, 1975, p. 85.

${ }^{31}$ ETCHEBERRY, Alfredo, El derecho penal en la jurisprudencia, t. I, Concepción: Samuel Muñoz Vera ed., p. 18. NOVOA MONREAL, Curso, cit. nota n ${ }^{\circ} 10$, pp. 120 y 121.

${ }^{32}$ ETCHEBERRY, Derecho Penal (parte general), cit. nota $\mathrm{n}^{\circ} 4$, pp. 85 y 86.
} 
cuales son los requisitos que debe cumplir la norma complementaria, y poco refieren del requisito sine lege scripta.

Avanzando en la precisión, preocupándose no sólo del contenido de la norma sino que, también, de su fuente de determinación (sine lege scripta), parte de la doctrina, ${ }^{33} \mathrm{y}$, también, la jurisprudencia, ${ }^{34}$ sostiene que dichos tipos penales no son inconstitucionales, si el núcleo fundamental o esencial de la conducta típica (su contenido de desvalor respecto de la lesión o puesta en peligro del bien jurídico) aparece descrito en la ley, junto con la sanción. El reglamento no puede definir la conducta punible, sino tan sólo indicar límites, condiciones o circunstancias y cualesquier otros elementos accidentales, complementarios o accesorios, porque es sólo una manifestación de la potestad reglamentaria de ejecución. ${ }^{35}$ Esto se conoce como "teoría de la esencialidad".

Finalmente, los tribunales alemanes han elaborado lo que se conoce como la "teoría de la concreción", en virtud de la cual la ley penal en blanco determina la conducta prohibida en términos ciertos, pero dejando a leyes de menor rango la función de concretar los criterios de decisión judicial, que fueron ya establecidos en la ley. ${ }^{36}$

\subsubsection{Toma de posición.}

a) Respecto de la Ley que contiene el tipo penal en blanco.

En mi opinión, para poder cumplir con la exigencia constitucional de "descripción expresa de la conducta" - teniendo en cuenta el significado de las palabras describir y expresa, y la no exigencia de que aquella sea completa $-{ }^{37}$ es preciso que el tipo penal se señale el núcleo

${ }^{33}$ SILVA BASCUÑÁN, Alejandro, Tratado de Derecho Constitucional, t. XI, Santiago: Editorial Jurídica de Chile, $2^{a}$ ed., 2006, pp. 173 a 180. CEA EGAÑA, José Luis, Tratado de la Constitución de 1980, Santiago: Editorial Jurídica de Chile, 1988, pp. 285 y 286. GARRIDO MONTT, Mario, Derecho Penal, parte general, t. I, Santiago: Editorial Jurídica de Chile, $1^{\mathrm{a}}$ ed., 1997, p. 91. CURY, La ley penal en blanco, cit. nota $\mathrm{n}^{\mathrm{o}} 1$, pp. 68 y ss., y en Derecho Penal (parte general), cit. nota n ${ }^{\circ}$, p. 179. BUSTOS RAMÍREZ, Obras Completas, cit. nota $\mathrm{n}^{\circ}$ 4, p. 388. YÁÑEZ PÉREZ, "Las Leyes penales en blanco", cit. nota no 1, p. 11. MATUS ACUÑA, Jean Pierre, La Ley Penal y su interpretación, Santiago: ed. Jurídicas Congreso, 1994, p. 46. RODRÍGUEZ COLLAO, "Constitucionalidad", cit. nota n $^{\circ}$ 6, p. 242.

${ }^{34}$ STC, de 04-12-1984, Rol N 24, publicada en Gaceta Jurídica, año X (1985), № 56, pp. 116 y ss.: "Es evidente que la modificación introducida por la H. Junta de Gobierno tuvo por objeto suprimir la exigencia de que la ley penal se baste en todo aspecto a sí misma y que, por el contrario, estimó que era suficiente que la ley tipificara en lo esencial la conducta delictual, la que podría ser desarrollada o precisada en aspectos no esenciales, por otra norma emanada de una instancia distinta a la legislativa.”. STC, de 26-08-1996, rol ํㅜ 244: "la Constitución precisa de manera clara que corresponde a la ley y sólo a ella establecer al menos el núcleo esencial de las conductas que se sancionan" (la cursiva es mía). STC, de 07-06-2007, rol N 559. SCS, de 28-01-1986, I.C. N²4.810, Gaceta Jurídica, Nº 69 (1986), pp. 34 a 42. SCS, de 16-07-2002, I.C. 47902002: "la carta fundamental sólo exige la descripción del núcleo básico del tipo, de la conducta prohibida, sin requerir la descripción completa y expresa del tipo penal, razón por la que se acepta que se entreguen a otras instancias de jerarquía inferior precisiones sobre las condiciones en que determinadas conductas serán sancionadas".

${ }^{35}$ Artículo $32 \mathrm{~N}^{\circ} 6$ y artículo $63 \mathrm{~N}^{\circ} 3$, ambos de la Constitución Política de 1980.

${ }^{36}$ GARCÍA CAVERO, Derecho Penal, cit. nota no 15 , p. 148.

37 Según diccionario de la Real Academia Española, "Describir: delinear, dibujar, figurar algo, representándolo de modo que dé cabal idea de ello. 3. definir imperfectamente algo, no por sus predicados esenciales, sino dando una idea general de sus partes o propiedades.". (la cursiva es mía); a su vez, 
esencial o básico de la conducta prescrita, que está formado por su verbo rector y por la faz subjetiva del tipo (dolo, imprudencia, elementos subjetivos del tipo), de tal manera que la forma verbal sea suficiente para determinar el significado de lo que se quiere manifestar, el sentido de la conducta prohibida, y así las personas conozcan y comprendan la esfera y contenido de desvalor de aquella y su bien jurídico protegido desde la propia ley penal, ${ }^{38}$ quedando los accidentes de su regulación (en qué ámbitos y bajo qué circunstancias la conducta punible será sancionada, así como el objeto material sobre el cual recae) en las normas complementarias. ${ }^{39}$

La determinación de si la conducta es dolosa o imprudente, o si tiene limitaciones o inclinaciones subjetivas, no puede quedar al arbitrio de la autoridad administrativa, pues estimo que forma parte del núcleo esencial de la descripción típica de la conducta, junto con el verbo rector.

\section{b) Respecto de la norma complementaria.}

Sobre su forma de comunicación, nuestra jurisprudencia, junto con indicar que la norma complementaria forma parte del tipo penal, ha manifestado que aquella deba cumplir con la exigencia de toda ley de publicarse en el Diario Oficial, aunque por su naturaleza no lo requiera. ${ }^{40}$ Esto me parece un exceso, aunque sí creo debe acreditarse una forma de publicación que permita, potencialmente, a los afectados por su regulación conocer su contenido; ${ }^{41}$ sobre todo, en las materias del ámbito económico, donde son más comunes este tipo de leyes, en que los actores de los distintos mercados tienen acceso a las diversas regulaciones técnicas o administrativas que les afectan.

En cuanto al contenido de la remisión normativa, si la norma complementaria se excede o aparta del texto legal, aquello no sólo es ilegal, sino también inconstitucional, de manera tal que puede cuestionarse por los jueces tal inclusión. Esta posición se funda en lo resuelto

\footnotetext{
"Expresar: 3. darse a entender por medio de la palabra"; y, finalmente, "Completamente. adv. m. Cumplidamente, sin que nada falte.".

${ }^{38}$ STC, de 04-12-1984, Rol No 24: "De acuerdo a los términos del inciso final del $\mathrm{N}^{\circ} 3$ del artículo 19, basta, pues, que la conducta que se sanciona esté claramente descrita en la ley, pero no es necesario que sea de un modo acabado, perfecto, de tal manera llena, que se baste a sí misma, incluso en todos sus aspectos no esenciales.". STC, de 30-03-2007, rol № 549: "El carácter expreso - claro, patente, especificado - que, conforme a la Constitución, debe contener la descripción de la conducta, no se identifica con totalidad o integridad, sino que está asociado a la comprensión y conocimiento por las personas de sus elementos esenciales.".

${ }^{39}$ CURY, La ley penal en blanco, cit. nota $\mathrm{n}^{\circ} 1$, pp. 62 y 63, sostiene que ya que el mandato de determinación se refiere a la conducta punible, y no a los presupuestos de la pena, el ámbito en que se puede desarrollar una ley penal en blanco abarca a las condiciones objetivas de punibilidad, las excusas legales absolutorias, los obstáculos procesales y las limitaciones al ejercicio de la acción penal; lo mismo que las circunstancias que rodean a la conducta, para las cuales no sería necesaria la exigencia de una ley en su determinación, admitiendo reenvío.

${ }^{40}$ Sentencia Corte de Apelaciones de Santiago, de 22-06-1963, Revista de Derecho y Jurisprudencia, t. LX (1963), p. 288. Exige la publicidad que rige para toda ley; e indica que, antes de su publicación auténtica, el hecho no resulta típico ni antijurídico. CURY, Derecho Penal (parte general), cit. nota $\mathrm{n}^{\circ}$ 4, p. 181. POLITOFF/MATUS/RAMÍREZ, Lecciones, cit. nota $\mathrm{n}^{\circ}$ 6, p. 97.

${ }^{41}$ STC, de 07-06-2007, Rol No 559, reconoció como forma de comunicación los planes y programas de estudio de las ramas castrenses.
} 
por el Tribunal Constitucional, a propósito de la Ley $\mathrm{N}^{\circ} 18.403$, al indicar “... se deje entregada al reglamento la misión de pormenorizar las substancias o drogas a que se refiere la norma rectora en nada se contrapone con la preceptiva constitucional, ya que no puede incluirse en el citado reglamento, lícitamente, ninguna substancia o droga que no quede comprendida dentro de aquellas que genéricamente se indican en ambos incisos del artículo $1^{\circ}$ del proyecto de ley" (la cursiva es mía). ${ }^{42}$ Aunque algunos pudieran pensar que esta sentencia sigue la teoría de la concreción, esto no es así, pues no se ha dejado al reglamento la función de concretar los criterios de decisión judicial, estos criterios son establecidos en la propia ley, el reglamento no puede ir en contra de ellos o excederse; en el caso de la ley de drogas, tales criterios se encuentran en los verbos rectores de las conductas y en la definición del objeto material. ${ }^{43}$

\section{Retroactividad e Irretroactividad de la ley penal en blanco.}

\subsection{Fundamentos.}

Conforme a la exigencia de Lex Previae, para que un comportamiento sea considerado delito debe aparecer descrito en una ley dictada con anterioridad a la fecha de su comisión, lo mismo que su sanción, pues ello es una manifestación del principio de legalidad en la búsqueda de la 'seguridad jurídica' ${ }^{44}$ Por ende, se prohíbe la dictación de leyes penales con efectos retroactivos, así como la aplicación de una ley penal a hechos acaecidos con anterioridad a su entrada en vigencia. ${ }^{45}$

El establecimiento del "principio de la irretroactividad de la ley penal", ${ }^{46}$ busca impedir la arbitrariedad, el ciudadano no puede quedar a expensas de la voluntad ocasional del legislador y de la intervención abusiva del Estado, con legislación que busque resolver casos ad hoc especialmente escandalosos en un momento determinado, negando la

${ }^{42}$ STC, de 04-12-1984, rol N² 24.
${ }^{43}$ Artículo 1, incisos 1 y 2 , de la Ley N $N^{\circ} 20.000$.
${ }^{44}$ LUZÓN PEÑA, Curso, cit. nota no 1 , pp. 133 a 137, 181 y 182. OLIVER CALDERÓN, Guillermo, LUZON PENA, Curso, cit. nota $\mathrm{n}^{\circ}$ 1, pp. 133 a 137, 181 y 182. OLIVER CALDERON, Guillermo, ss., en la nota 72 entrega un completo listado de autores que fundan la irretroactividad en la seguridad jurídica. GARRIDO MONTT, Derecho Penal (parte general), cit. nota $\mathrm{n}^{\mathrm{o}}$ 33, p. 106. BASCUÑ́́N RODRÍGUEZ, Antonio, "La aplicación de la ley penal más favorable", Revista Jurídica de la Universidad de Puerto Rico, vol. 69, $\mathrm{N}^{\circ} 1$ (2000), p. 38. En una posición algo diferente, RODRÍGUEZ COLLAO, Luis, "Sobre el papel de la jurisprudencia en la generación del derecho penal", Revista de Derecho, Universidad Católica de la Santísima Concepción, vol. VI, № 6 (1998), p. 198, para quien - sin perjuicio de reconocer el efecto de seguridad jurídica - es más un instrumento de garantía del individuo frente a los poderes estatales.

${ }^{45}$ Actas oficiales de la Comisión de Estudios de la Nueva Constitución, sesiones 111, 112 y 113, de fechas 3, 8 y 10-04-1975. Artículo 19 N 3, inciso 7, de la Constitución Política de 1980; artículo 18 del C. P.; artículo 11.2 de la Declaración Universal de los Derechos del Hombre; artículo 9 de la Convención Americana sobre Derechos Humanos; y, artículo 15 del Pacto Internacional de Derechos Políticos y Civiles. BASCUÑ ÁN RODRÍGUEZ, Antonio, "La Ley Penal”, Revista de Derecho de la Universidad Adolfo Ibáñez, N² (2005), p. 362.

${ }^{46}$ Según POLITOFF, Sergio; MATUS Jean Pierre, "Comentario preliminar al art. 18. Aplicación temporal de la Ley Penal”, en POLITOFF, Sergio; ORTIZ, Luis (Dir.); MATUS, Jean Pierre (Coord.), Texto y comentario del Código Penal Chileno, t. I, Santiago: Editorial Jurídica de Chile, 2002, p. 263, "El principio de irretroactividad de la ley penal es también una consecuencia lógica del principio de lex certa, que está contenido, de modo implícito, en el artículo $1^{\circ}$ del CP.’. 
posibilidad de crear delitos y/o penas ex post facto, y, por ello, es que en aras de dar "Seguridad Jurídica" a los habitantes, de que no verán afectadas sus libertades individuales en forma arbitraria por parte de los órganos del Estado, no se puede conceder efecto retroactivo a las leyes punitivas, pues de lo contrario "no podrían saber a qué atenerse" al momento de comportarse. ${ }^{47}$

Por lo tanto, un hecho debe ser sancionado criminalmente de acuerdo con la ley penal vigente al momento de su comisión. Esta garantía para el ciudadano es, también, una prohibición para los jueces, quienes no pueden aplicar una ley penal a hechos acaecidos con anterioridad a su entrada en vigencia. La Seguridad Jurídica es, en consecuencia, expresión del fundamento político liberal que inspira al principio de legalidad.

Se ha sostenido, por otros autores, ${ }^{48}$ que sólo un sujeto que está en condiciones de conocer que una conducta está prohibida, y que la violación de dicha prohibición le acarreará una sanción penal, puede motivarse por dicha norma y ser susceptible de ser considerado imputable por haber infringido culpablemente el ordenamiento penal. Constituye una garantía para el ciudadano, ${ }^{49}$ porque sólo se lo sanciona por infringir un mandato previo, del cual su autor pudo tener conciencia de estar infringiendo la norma, ${ }^{50}$ y no se adecuo como era debido. Se sostiene, también, que las normas penales son reglas que buscan prevenir la comisión de delitos en el futuro ${ }^{51}$ o, que se funda en el más elemental concepto de justicia. $^{52}$

Sin perjuicio de lo anterior, la Seguridad Jurídica que se pretende conceder a los ciudadanos con la exigencia de lex praevia no se verá afectada por el reconocimiento de la retroactividad de la ley penal más benigna, porque ella no atenta contra las libertades individuales de los ciudadanos que pretende proteger la seguridad jurídica.

En un Estado Democrático de Derecho, ${ }^{53}$ la justificación del uso del ius puniendi debe cumplir cinco condiciones: a) que el fin perseguido por el Estado sea en sí mismo legítimo; b) que el medio utilizado para alcanzar dicho fin sea, también, en sí legítimo; c) que tal medio sea idóneo para alcanzar dicho fin; d) que el medio empleado sea necesario para alcanzar el fin; y, e) que la afectación del derecho sea proporcionada con la realización del

\footnotetext{
${ }^{47}$ PÉREZ LUÑO, Antonio, La Seguridad Jurídica, Barcelona: ed. Ariel, 1991, p. 8.

48 Sobre las distintas teorías, OLIVER CALDERÓN, Guillermo, "El fundamento del principio de irretroactividad de la ley penal", Revista de Derecho de la Universidad Católica de Valparaíso, XXI (2000), pp. 95 y ss.

${ }^{49}$ BLANCO LOZANO, Carlos, "El principio de vigencia en el derecho penal", Revista de Derecho, Criminología y Ciencias Penales, año II, $\mathrm{N}^{\circ} 2$ (2000), p. 195. NOVOA MONREAL, Curso, cit. nota nº 10, p. 117, para quien, así, se asegura el respeto de la libertad y dignidad de la persona humana.

${ }^{50}$ ROXIN, Derecho Penal (parte general), cit. nota n ${ }^{\circ}$ 16, pp. 146 y 147. SILVA SÁNCHEZ, Jesús María, "Legislación penal socio-económica y retroactividad de disposiciones favorables: el caso de las «leyes en blanco»", en: Hacia un derecho penal económico europeo, jornadas en honor del profesor Klaus Tiedemann, Madrid: Boletín Oficial del Estado, Estudios Jurídicos, Serie Derecho Público, 1995, p. 698. BACIGALUPO, Enrique, Derecho Penal, parte general, Lima: Ara editores, 2004, p. 103, para quien es una garantía de objetividad del juicio sobre el hecho.

${ }^{51}$ Función motivadora de la norma penal y prevención general. Por todos, ROXIN, Derecho Penal (parte general), cit. nota $\mathrm{n}^{\circ} 16$, p. 146.

${ }_{52}$ MUÑZ CONDE/GARCÍA ARÁN, Derecho Penal (parte general), cit. nota no 11, p. 138.

${ }^{53}$ BASCUÑÁN RODRÍGUEZ, "La Ley Penal", cit. nota n 45 , p. 364.
} 


\section{Polit. crim., Vol. 4, No 7 (Julio 2009), Art. 4, pp. 125-150 (1-26). \\ [http://www.politicacriminal.cl/Vol_04/n_07/Vol4N7A4.pdf]}

fin perseguido. Por este motivo, constitucionalmente se admite una excepción al principio de la irretroactividad de la ley, cual es la aplicación retroactiva de la ley penal dictada con posterioridad a la comisión del hecho, en caso de que ésta sea más favorable para el acusado, pues político criminalmente la valoración legal de dicha conducta al momento de sentenciar es menos gravosa que al momento de su comisión. ${ }^{54}$

La retroactividad de la ley penal más favorable, entonces, se justifica - así lo indica el artículo 18 del C. P. - por la existencia de normas que reducen la punibilidad de una conducta o que eliminan un hecho determinado del ámbito de lo punible; o sea, se funda en la proporcionalidad y en la necesidad de la pena, ${ }^{55}$ debido a que no es dable mantener penas que el ordenamiento jurídico actualmente considera excesivas (por existir desproporción entre la lesividad del daño ocasionado y la afectación de los derechos del imputado) o innecesarias. ${ }^{56}$ Enfrentado a esta situación, se permite al juzgador hacer una ponderación de proporcionalidad y necesidad de pena al momento de definir la procedencia de la aplicación retroactiva de una ley; y, por eso, se sostiene que la Constitución autorizó la aplicación retroactiva de la ley más benigna, y no estableció un mandato de aplicación retroactiva, a diferencia de lo que ocurre con la obligación de la irretroactividad de leyes penales desfavorables. $^{57}$

\subsection{Evolución de la valoración jurídico - penal.}

La prohibición general de retroactividad de la ley penal se ve enfrentada, en la práctica, a dos situaciones diversas, y que son: ${ }^{58}$

\subsubsection{Continuidad del injusto (sucesión de leyes penales).}

Se dice que existe sucesión de leyes penales, en sentido estricto, en aquellos casos en que se produce una modificación o cambio del tratamiento penal de una misma situación de hecho que ya era considerada como punible por la legislación, disminuyendo, aumentando o agravando su penalidad. Se considera que abarca, también, la derogación de una figura penal.

\footnotetext{
${ }^{54}$ MIR PUIG, Derecho Penal (parte general), cit. nota ${ }^{\circ} 1$, pp. 116, 122 y ss. MATUS ACUÑA, Jean Pierre, "Dos problemas de aplicación retroactiva de la ley penal favorable", Revista de Derecho Penal, N 19 (2006), p. 74.

55 SCS, de 16-05-1945, Revista de Ciencias Penales, vol. VIII, pp. 134 y 135, "a la fecha de dictación del fallo... ya había desaparecido la prohibición de celebrarlo mediante autorización... era absolutamente innecesario y sin trascendencia penal alguna lo actuado por Villanueva para contraer el vínculo".

56 SILVA SÁNCHEZ, "Legislación penal”, cit. nota n 50, p. 699. LASCURAÍN SÁNCHEZ, Sobre la retroactividad, cit. nota $\mathrm{n}^{\circ}$ 14, p. 39. NOVOA MONREAL, Curso, cit. nota $\mathrm{n}^{\circ} 10$, p. 199, considera que son razones de justicia, para evitar la aplicación de penas innecesarias o excesivas "y, por consiguiente, injustas.". SCS, de 21-08-2006, I.C. $N^{\circ}$ 1647-2003: "El objetivo, en definitiva, es hacer más benigna la intervención del Estado, lo que es expresión del principio de necesidad de la intervención penal".

57 BASCUÑÁN RODRÍGUEZ, Antonio, "Ley Penal”, Revista de Derecho de la Universidad Adolfo Ibáñez, $\mathrm{N}^{\circ} 1$ (2004), p. 212. LUZÓN PEÑA, Curso, cit. nota nº 1, p. 182.

${ }^{58}$ CEREZO MIR, José, Derecho Penal, parte general, Montevideo/Buenos Aíres: ed. BdeF Ltda., 2008, pp. 217 y ss.
} 
Es este el fenómeno en que tiene trascendencia la irretroactividad de la ley penal, y su excepción constitucional. ${ }^{59}$

\subsubsection{Creación de un tipo penal nuevo.}

En sentido amplio, constituye, también, para algunos, un caso de sucesión de leyes penales; ${ }^{60}$ en realidad, se trata de la alteración del tratamiento jurídico penal de una conducta que antes de la entrada en vigencia de la nueva ley no era sancionada penalmente. En este caso, a diferencia del anterior, no puede existir excepción al principio de la irretroactividad de la ley penal, porque a la época de la conducta no existía el desvalor propio de un injusto penal a su respecto.

\subsection{Retroactividad de las normas complementarias de una ley penal en blanco.}

Las normas complementarias se integran al contenido de la ley penal y le son aplicables sus principios y limitaciones. ${ }^{61}$ Sin embargo, pese a lo anterior, ha habido diversas teorías respecto de la posibilidad de reconocer o no efecto retroactivo a la modificación de normas jurídicas reglamentarias favorables al imputado. Haremos referencia a las más representativas.

\subsubsection{Teorías contrarias al efecto retroactivo.}

a) Teoría de la diferenciación entre ley y norma.

Postula que a las normas complementarias no cabe reconocerles efecto retroactivo más favorable, pues estas normas no son leyes, y sólo a la modificación de las leyes se les concede este beneficio de aplicación retroactiva.

\section{b) Teoría de la desobediencia.}

Sostiene que la esencia del injusto penal radica en la desobediencia a la norma de determinación, que obliga a cumplir las leyes y reglamentos con independencia de su contenido, y resulta que la modificación del contenido de la norma penal no afecta la norma de obedecer que sigue inalterable.

2.3.2. Teorías que reconocen efecto retroactivo a la modificación de la norma complementaria.

\footnotetext{
${ }^{59}$ Por todos, OLIVER CALDERÓN, Retroactividad e irretroactividad, cit. nota $\mathrm{n}^{\circ} 44$, pp. 45 y ss.

${ }^{60}$ MUÑOZ CONDE/GARCÍA ARÁN, Derecho Penal (parte general), cit. nota ${ }^{\circ} 11$, pp. 136 y 137. OLIVER CALDERÓN, Retroactividad e irretroactividad, cit. nota ${ }^{\circ}$ 44, p. 48.

${ }^{61}$ GARRIDO MONTT, Derecho Penal (parte general), cit. nota no 33, pp. 107 y 113. BUSTOS RAMÍREZ, Juan, Manual de Derecho Penal, Barcelona: ed. Ariel S.A., $3^{\text {a }}$ ed., 1989, p. 85. MATUS ACUÑA, "Dos problemas de aplicación retroactiva", cit. nota $\mathrm{n}^{\circ}$ 54, p. 65. OLIVER CALDERÓN, Retroactividad e irretroactividad, cit. nota $\mathrm{n}^{\circ} 44$, pp. 138 y ss. y 340 y ss. GARCÍA CAVERO, Derecho Penal, cit. nota $\mathrm{n}^{\circ} 15$, p. 254 y ss. CEREZO MIR, Derecho Penal (parte general), cit. nota $n^{\circ}$ 58, p. 219. SILVA SÁNCHEZ, "Legislación penal", cit. nota no 50, p. 715. TIEDEMANN, "La ley penal en blanco", cit. nota nº 6, p. 76.
} 


\section{Polit. crim., Vol. 4, No 7 (Julio 2009), Art. 4, pp. 125-150 (1-26). \\ [http://www.politicacriminal.cl/Vol_04/n_07/Vol4N7A4.pdf]}

En oposición a las construcciones formales antes señaladas, existen teorías materiales que reconocen efecto retroactivo a la normativa complementaria, siempre que dicho efecto suponga ser más favorable para el imputado. Las más destacadas o reconocidas son:

\section{a) Teoría unitaria.}

Según sus partidarios, es ley penal toda norma que contenga definición de delitos y sus consecuencias penales, así como toda aquella norma que se incorpore al tipo penal para completar su sentido, si constituyen presupuestos de la imposición de la sanción penal. Para esta teoría, por ende, al modificarse la norma complementaria se puede modificar, también, el ámbito del injusto; y, de ser así, quedar sometida dicha modificación a las normas de retroactividad más favorable.

\section{b) Teorías de las modificaciones debido a cambios fácticos.}

No existe aplicación retroactiva de la modificación a la norma complementaria, cuando dicha modificación se refiere sólo a una modificación o cambio de circunstancias; pero, si tendrá efecto retroactivo, en caso de que signifique un cambio en la valoración jurídica. ${ }^{62}$

\section{c) Teoría de la afección al núcleo del injusto.}

Debe distinguirse si la norma de complemento afecta al núcleo del injusto (su fin de protección o la forma de ataque indicada en el tipo), de aquella que sólo afecta al objeto material y otros aspectos fácticos, reconociendo efecto retroactivo a la modificación del primer tipo de normas complementarias y negándoselo a los otros.

\section{d) Teoría de los especiales fines del Derecho Penal.}

Según esta teoría, se requiere que la ratio legis de la modificación responda a una modificación de la valoración jurídica del hecho y no a un mero cambio fáctico de las circunstancias, porque en este último caso el comportamiento realizado en un momento anterior sigue desvalorado y es sujeto a sanción penal. ${ }^{63}$ Así, sólo puede entenderse como más beneficiosa para el imputado aquella modificación legal que hace desaparecer la necesidad preventivo general y especial de la pena para el hecho que cometió antes de la modificación. ${ }^{64}$ En los demás casos, en que no desaparece dicha necesidad preventiva, no debe darse efecto retroactivo a la modificación de la norma de complemento, aunque aquella sea más favorable, pues sigue habiendo necesidad preventivo general y especial de pena para dicha conducta que aún es lesiva a un bien jurídico protegido penalmente con el mismo tipo penal. El problema es que sólo reconoce la necesidad de pena, pero reniega del problema de proporcionalidad.

\subsubsection{Toma de posición.}

\footnotetext{
${ }^{62}$ SANTANA VEGA, El concepto, cit. nota n ${ }^{\circ}$ 2, p. 90. CURY, Derecho Penal (parte general), cit. nota $\mathrm{n}^{\circ} 4$, p. 233. Sobre sus dificultades, LASCURAÍN SÁNCHEZ, Sobre la retroactividad, cit. nota $\mathrm{n}^{\circ} 14$, pp. 47 y ss. ${ }^{63}$ SILVA SÁNCHEZ, "Legislación penal”, cit. nota no 50, p. 715.

${ }^{64}$ SILVA SÁNCHEZ, "Legislación penal", cit. nota n 50, pp. 720 y 721, para quien el criterio decisivo es la falta de necesidad de pena.
} 
En mi opinión, para que una modificación en la norma reglamentaria tenga efecto retroactivo como ley penal más benigna, es preciso que altere significativamente una institución penalmente protegida, dejándola sin efecto ni protección jurídico-penal, ${ }^{65} \mathrm{o}$, al menos, que signifique una disminución efectiva, obligatoria, y no meramente facultativa, del marco penal. ${ }^{66}$

Obviamente, debe existir un límite, pues no cualquier modificación de la norma complementaria va a significar una modificación de la valoración jurídica de la conducta, que permita ser considerada como modificadora del tipo penal. Así, si varía el grado alcohólico en los parámetros del manejo en estado de ebriedad, o el límite en la contaminación del agua en un delito ambiental, o la velocidad máxima en una carretera, no se modifica en nada la ilicitud del respectivo delito ya cometido, por lo que no podría exigirse su aplicación retroactiva. ${ }^{67}$ Distinto es que se estableciera que tal residuo vertido no es contaminante, porque en ese caso su exclusión significa una alteración en la valoración jurídica que debe producir efectos retroactivos.

\subsection{Presupuestos de ley penal más favorable.}

2.4.1. Determinación de la ley penal más favorable.

Para los efectos de determinar si la ley posterior - en el caso de esta investigación, si la modificación de la norma complementaria - es más favorable, debe tenerse en cuenta que lo es no sólo en caso suprimir o disminuir la punibilidad del hecho, sino incluso en aquellos casos en que se altera la descripción del tipo penal incorporando exigencias que antes no existían. $^{68}$

a) Si se modifica la sanción penal.

Para determinar la ley más favorable se debe estar al caso concreto, ${ }^{69}$ comparándose la pena que corresponda en abstracto al delito (según si es doloso o imprudente, en su caso), su iter criminis y el grado de participación que corresponde al sujeto, por separado, de acuerdo con ambas leyes. No basta sólo con comparar la escala de penas que corresponde en abstracto al delito consumado, sino que debe tenerse en cuenta los distintos factores en la determinación de la pena en concreto de cada caso; debe compararse la naturaleza de las sanciones, en cuanto a su duración y aflictividad; incluso, debe considerarse el juego de las circunstancias

\footnotetext{
${ }^{65}$ DE LUCA, Javier Augusto, Leyes penales más benignas, en blanco y Constitución Nacional, Buenos Aires: ed. Ad-Hoc, 1997, p. 17.

${ }^{66}$ Por todos, NOVOA MONREAL, Curso, cit. nota n ${ }^{\circ}$ 10, p. 202.

${ }^{67}$ CURY, Derecho Penal (parte general), cit. nota $n^{\circ} 4$, p. 233.

${ }^{68}$ CURY, Derecho Penal (parte general), cit. nota no 4, p. 229. POLITOFF/MATUS, "Comentario preliminar al art. 18 ", cit. nota n 46 , pp. 267 y 268.

${ }^{69}$ ETCHEBERRY, El Derecho Penal en la jurisprudencia, cit. nota $\mathrm{n}^{\circ}$ 31, pp. 121 a 125. CERDA SAN MARTÍN, Rodrigo; HERMOSILLA IRIARTE, Francisco, Código Penal, jurisprudencia en el nuevo sistema de justicia criminal, Santiago: Librotecnia, $3^{\mathrm{a}}$ ed., 2008, pp. 159 a 171. VERDUGO MARINKOVIC, Mario, Código Penal, t. I, Santiago: ed. Jurídicas Ediar-Conosur Ltda., 2ª ed., 1986, pp. 184 a 187.
} 
agravantes y atenuantes, eximentes, y las normas de prescripción, ${ }^{70}$ pues la nueva ley puede incluir circunstancias nuevas o autorizar o negar el uso de otras ya existentes, que determinarán una modificación de la pena efectiva que se deba aplicar. ${ }^{71}$ La nueva ley puede, también, contener normas desfavorables para el agente, las que deberán aplicarse si se opta por la ley nueva. Lo concreto es que, en su sentencia, el juez debiera determinar la pena aplicando por separado ambas leyes, y, luego, optar por aquella que sea más benigna, en el caso concreto, para el imputado.

\section{b) Si se produce una reformulación de los delitos.}

Esto ocurre en aquellos casos en que una nueva norma penal deroga una conducta típica y la reemplaza por otra similar respecto de la misma conducta, cambiando la estructura del tipo penal; o, en aquellos casos en que, sin derogar la conducta, modifica su estructura; e, incluso, en aquellos en que se deroga una conducta típica, que era una figura especial en relación con otra de carácter general que continua vigente. ${ }^{72}$

No cabe duda que es más favorable si la modificación significa la impunidad del hecho, deja de ser delictivo; de no ser así, en mi opinión, debe aplicarse el criterio de la continuidad del tipo del ilícito y comparar los tipos previstos en las leyes sucesivas en relación al bien jurídico protegido y a la modalidad de ataque al mismo (verbo rector), de tal manera que si existe coincidencia en dichos ámbitos se puede afirmar la continuidad o ultraactividad de leyes penales. ${ }^{73}$ Una vez determinado lo anterior, el establecimiento de la ley penal más favorable deberá regirse por lo indicado a propósito de la modificación de la sanción penal.

\subsubsection{Prohibición de Lex Tertia.}

La doctrina mayoritariamente afirma que el juzgador no puede, al momento de determinar la ley penal más favorable, realizar una aplicación mixta o parcial de las distintas leyes en comparación, eligiendo lo más favorable de cada una de ellas, puesto que aquello significa no ya la aplicación de la ley más favorable, sino que la creación jurisprudencial de una nueva tercera ley (lex tertia), que no existe como tal, cuestión que está prohibida

\footnotetext{
${ }^{70}$ BLANCO LOZANO, "El principio de vigencia", cit. nota n ${ }^{\circ} 49$, p. 200. COUSIÑO, Derecho Penal (parte general), cit. nota $\mathrm{n}^{\circ} 30$, p. 130. NOVOA MONREAL, Curso, cit. nota $\mathrm{n}^{\circ} 10$, p. 200. SCS, de 21-08-2006, I. C. $\mathrm{N}^{\circ}$ 1647-2003: "se ha entendido que una ley es más favorable no sólo cuando se suprime o disminuye directamente la punibilidad del hecho, sino también cuando se consagran eximentes de responsabilidad penal o atenuantes que lo benefician".

${ }^{71}$ SCS, de 22-06-1998, I.C. N ${ }^{\circ}$ 1.463-1998: "los tribunales considerarán preferentemente la ley posterior más benigna, ya sea que derogue el delito, establezca circunstancias modificatorias que la eximan o atenúen su responsabilidad o disponga una pena menos rigurosa".

${ }^{72}$ Sobre los diversos criterios, GARCÍA CAVERO, Derecho Penal, cit. nota $\mathrm{n}^{\circ}$ 15, pp. 53 a 56 . GARRIDO MONTT, Derecho Penal (parte general), cit. nota n³3, pp. 108 y 109.

${ }^{73}$ SCS, de 20-04-2005, I.C. N ${ }^{\circ}$ 5093-2002: “Que, sólo basta constatar el contenido de la norma del artículo 29 de la Ley 19.733, para entender que ella dejó prácticamente inalterable la contenida en el artículo 21 de la antigua Ley 16.643 y con ello el tipo penal mismo...". SCS, de 21-08-2006, I.C. N ${ }^{\circ}$ 1647-2003: “es útil enfatizar que del cotejo de los verbos rectores y demás elementos del tipo, entre el artículo 366 anterior a la reforma de las leyes 19.617 y 19.927 , con los preceptos originados por ellas, surge de manifiesto que se mantiene total identidad de los verbos rectores, y lo único que se hace... es organizar en distintas disposiciones las mismas conductas... en modo alguno ha implicado la supresión del delito mismo".
} 
constitucional (lege scripta) y legalmente a los jueces. ${ }^{74}$ Sin embargo, en forma equivocada, la jurisprudencia en algunos casos ha hecho aplicación de lex tertia. ${ }^{75}$

\section{Problemas prácticos.}

\subsection{En la Ley $\mathbf{N}^{\circ} \mathbf{2 0 . 0 0 0}$, por cambios en su reglamento.}

Nuestra legislación, en esta materia, adoptó la técnica de las leyes penales en blanco, haciendo un reenvío a un reglamento, en cuanto a la determinación del objeto material cuyo tráfico se sanciona ${ }^{76}$ lo que se concretó en la elaboración de cinco listados diferenciadores de drogas, materias primas y precursores. ${ }^{77}$

La última modificación del reglamento sobre la materia significó trasladar a la Cannabis desde el listado de las drogas que no producen efectos tóxicos ni daños considerables a la salud al listado de las drogas que sí producen esos efectos, adecuando de esta manera nuestra clasificación del Cannabis a aquella que ya reconocen los tratados internacionales vigentes en Chile.

\subsubsection{Concepto normativo de droga prohibida.}

\section{a) Definición legal.}

Para nuestra ley, es aquella sustancia o droga estupefaciente o psicotrópica "productora de dependencia física o psíquica"; ${ }^{78}$ he ahí el elemento central, pues la masificación descontrolada de su consumo debido a la dependencia física y/o síquica que genera a sus consumidores, afecta, sobre todo, la salud pública de aquellos grupos de personas o comunidades que se ven involucradas por su difusión. ${ }^{79}$ Díez Ripollés, resalta que la dependencia que produce el consumo de drogas es el elemento decisivo. ${ }^{80}$ En el mismo

\footnotetext{
${ }^{74}$ LUZÓN PEÑA, Curso, cit. nota no 1, p. 187. CEREZO MIR, José, Curso de Derecho Penal Español, parte general, t. II, Madrid: ed. Tecnos, $5^{\text {a }}$ ed., 1997, p. 234. MUÑOZ CONDE/GARCÍA ARÁN, Derecho Penal (parte general), cit. nota $\mathrm{n}^{\circ} 11$, p. 144. ETCHEBERRY, Derecho Penal (parte general), cit. nota $\mathrm{n}^{\circ} 4, \mathrm{p} .144$. NOVOA MONREAL, Curso, cit. nota no 10, p. 201. BASCUÑÁN RODRÍGUEZ, "La ley penal”, cit. nota n 45, pp. 369 a 371. CURY, Derecho Penal (parte general), cit. nota $\mathrm{n}^{\circ} \quad 4, \quad \mathrm{p} .229$. POLITOFF/MATUS/RAMÍREZ, Lecciones, cit. nota $\mathrm{n}^{\circ}$ 6, p. 131. En posición contraria, BUSTOS RAMÍREZ, Juan, Manual de Derecho Penal, parte general, Barcelona: $4^{\mathrm{a}}$ ed., 1994, pp. 179 y ss.

${ }^{75}$ SCS, de 02-05-2002, I.C. $\mathrm{N}^{\circ}$ 3.382-2001, reconoció la derogación de la pena de muerte por la ley $\mathrm{N}^{\circ}$ 19.734, y aplicó la pena de presidio perpetuo simple indicando que era la pena más grave que seguía en la escala de penas de la antigua ley, rechazando la aplicación del presidio perpetuo calificado que incorporó la ley nueva. SCS, de 05-06-2002, I.C. N 622-2002.

${ }^{76}$ REY HUIDOBRO, Luis Fernando, El delito de tráfico de drogas. Aspectos procesales y penales, Valencia: ed. Tirant lo Blanch, 1999, pp. 112 y 113.

${ }_{77}$ Artículos 1 a 5 del Decreto N 565/1995, de Justicia, publicado en Diario Oficial de 26-01-1996.

${ }^{78}$ Artículo 1, inciso 1, de la Ley N²0.000. Artículo 2 del Convenio sobre Sustancias Sicotrópicas, de 1971.

${ }^{79}$ MATUS ACUÑA, Jean Pierre, "El tráfico ilícito de estupefacientes, en sentido amplio, como figura básica en los delitos de la ley N ${ }^{\circ}$ 19.366", en: POLITOFF L., Sergio; MATUS A., Jean Pierre (Coords.), Tratamiento Penal del Tráfico Ilícito de Estupefacientes. Estudios de dogmática y jurisprudencia, Santiago: ed. Lexis Nexis, 1998, pp. 128 y 130.

80 DÍEZ RIPOLLÉS, José Luis, Los delitos relativos a drogas tóxicas, estupefacientes y sustancias psicotrópicas, Madrid: ed. Tecnos, 1989, p. 38.
} 
sentido, Cobo del Rosal ha dicho que estas sustancias afectan la capacidad de decisión, y la libertad, de sus consumidores. ${ }^{81}$

La misma ley nos indica que estas drogas estupefacientes o sicotrópicas son de dos tipos: aquellas que sean capaces de provocar graves efectos tóxicos o daños considerables a la salud, y aquellas que no producen estos efectos. La definición legal nos entrega, entonces, criterios normativos para determinar si estamos en presencia o no de una droga regulada como prohibida por esta ley.

\section{b) Descripción nominal.}

El reglamento establece, en sus artículos 1 a 5, a partir de los conceptos dados en la ley, listas taxativas en las que se detallan las sustancias, materias primas o precursores cuyo tráfico se prohíbe.

\subsubsection{Formas o sistemas de determinación del objeto material.}

¿Debe el juez regirse por el listado de drogas indicado en el reglamento o puede aplicar un concepto propio a partir de la definición legal? Algunos autores estiman que el juez puede construir un concepto propio, valorando en cada caso concreto los efectos de la sustancia sobre la salud pública. ${ }^{82}$ Por el contrario, por razones de seguridad jurídica, la doctrina mayoritaria sostiene que los jueces no pueden apartarse de la descripción nominal dada por las listas de sustancias prohibidas. ${ }^{83}$

En realidad, la definición que buscamos se trata de un concepto normativo cuyo contenido ha de ser llenado por nuestra jurisprudencia, a partir de las definiciones legales y listados antes explicitados. Esta opinión concuerda con lo señalado en el artículo 63 de la Ley $\mathrm{N}^{\circ}$ 20.000, por lo que necesariamente la definición legal debe unirse a los listados indicados en el Reglamento. Sin embargo, si el Reglamento incorpora a alguno de los listados de drogas sustancias que no cumplen con la definición legal, esto es, no son drogas estupefacientes o sicotrópicas que produzcan dependencia física o psíquica, el Juez puede y debe cuestionar

${ }^{81}$ COBO DEL ROSAL, Manuel, "Consideraciones generales sobre el denominado 'tráfico ilegal de drogas tóxicas o estupefacientes"”, en Drogodependencias. Actas del IX Congreso Internacional, Madrid, 1980, pp. 191 y ss. y 201, citado por BERISTAÍN, Antonio, S.J. La Droga, aspectos penales y criminológicos, Bogotá: ed. Temis, 1986, p. 13.

${ }^{82}$ MUÑOZ CONDE, Francisco, Derecho Penal, parte especial, Valencia: ed. Tirant Lo Blanch, 1995, p. 566, quien estima que la enumeración del listado de drogas prohibidas desempeña un papel orientador para el juez, pero subordinado al bien jurídico protegido. GARCÍA CAVERO, Derecho Penal, cit. nota $\mathrm{n}^{\circ}$ 15, p. 151, afirma que el Juez puede dejar de lado la norma complementaria y regirse únicamente por la ley, si estima que existe conflicto entre ambas normas. BUSTOS RAMÍREZ, Juan, Obras Completas. Derecho Penal, parte Especial, $t$. III, Santiago: ed. Jurídicas de Santiago, 2a ed., 2009, p. 591, sostiene que "no puede significar que su contenido quede agotado por ellas. El juez no puede quedar totalmente vinculado". BERISTAÍN, Antonio, Cuestiones penales y criminológicas, Madrid: ed. Reus, 1979, citado por SEQUEROS SAZATORNIL, Fernando, El tráfico de drogas ante el ordenamiento jurídico, Madrid: ed. La Ley, p. 84; sin embargo, luego, cambia su postura, en La Droga, Aspectos, cit. nota n ${ }^{\circ} 81$, p. 30, indicando "las listas suponen para el tribunal una presunción iuris et de iure de que sus sustancias poseen las cualidades necesarias para el desvalor de la conducta y el desvalor del resultado.”.

${ }^{83}$ Por todos, SEQUEROS SAZATORNIL, El tráfico de drogas, cit. nota no 82, p. 85. REY HUIDOBRO, El delito de tráfico de drogas, cit. nota $\mathrm{n}^{\mathrm{o}} 76$, pp. 104 y ss. 
la constitucionalidad de su inclusión, y para ello tendrá como respaldo lo resuelto por el Tribunal Constitucional a propósito de la Ley $\mathrm{N}^{\circ} 18.403 .{ }^{84}$

¿Sólo debemos considerar las drogas incluidas en el reglamento, o también las incluidas en los listados de los tratados internacionales? En España, su ley penal hace directamente la remisión a los tratados internacionales. En Chile, en cambio, ha sido un Reglamento Sanitario el que ha elaborado y actualizado el contenido de los distintos listados. La Corte Suprema no se ha pronunciado sobre este problema, al parecer porque no ha sido objeto de discusión o cuestionamiento. Al encontrarse vigente en Chile tratados internacionales que, también, contienen listados similares al del reglamento, si dichos instrumentos coinciden, debe estarse a lo que en ellos se indica; sin embargo, en caso de existir discrepancias entre el reglamento y los tratados en la incorporación y/o ubicación de una sustancia, deberá el Juez en el caso concreto decidir cómo calificar la sustancia utilizando la definición legal de droga, y estableciendo a cuál de los dos tipos de sustancia estupefaciente o psicotrópica pertenece. Como límite básico de lo punible, si la sustancia no está contenida en el Reglamento, su posesión o tráfico no sería sancionable.

\subsubsection{Aplicación retroactiva de un cambio de ubicación en los listados del reglamento.}

La droga denominada Cannabis, antes y después de la modificación de su ubicación en el reglamento, siempre ha formado parte del objeto material de los delitos contemplados en los artículos 1 y 3 de la Ley $\mathrm{N}^{\circ} 20.000$, los cuales abarcan sin distinción a las drogas contenidas en ambos listados.

El inciso 2 del artículo 1 de la Ley $\mathrm{N}^{\circ} 20.000$ no contiene una conducta punible y una sanción, estructura propia de un tipo penal, no es una conducta típica distinta a la regulada en el inciso 1 de dicho artículo, ni forma parte del tipo penal. Tampoco es una circunstancia atenuante especial, porque de serlo su aplicación sería obligatoria al momento de determinarse la pena, de acuerdo con los artículos 62 y siguientes del C. P., lo que no es posible. Se trata de una norma de rebaja de pena cuya utilización es facultativa para el juez, quien en el caso concreto podrá aplicarla o no según su criterio, adecuándose a la definición legal de sustancia estupefaciente y a lo indicado en los artículos 1 y 2 del Reglamento, utilizando para ello como criterio o guía de su interpretación el principio de proporcionalidad.

Teniendo esto presente, es posible afirmar que no existe con el cambio de ubicación de la Cannabis una modificación de la valoración jurídica del delito, no existe una reformulación del mismo ni de su sanción, presupuestos necesarios para distinguir una ley penal más favorable o menos favorable.

a) Posesión o venta a terceros de marihuana (cannabis), cometida antes de la modificación al reglamento y juzgada con posterioridad a dicha modificación.

${ }^{84} \mathrm{STC}$, de 04-12-1984, rol $\mathrm{N}^{\circ}$ 24: "no puede incluirse en el citado reglamento, lícitamente, ninguna substancia o droga que no quede comprendida dentro de aquellas que genéricamente se indican en ambos incisos del artículo $1^{\circ}$ del proyecto de ley" (la cursiva es mía). 


\section{Polit. crim., Vol. 4, No 7 (Julio 2009), Art. 4, pp. 125-150 (1-26). \\ [http://www.politicacriminal.cl/Vol_04/n_07/Vol4N7A4.pdf]}

En este caso, el núcleo esencial de las conductas descritas en los artículos 1 y 3 de la Ley $\mathrm{N}^{\circ} 20.000$ no han sido modificados, la producción y el tráfico ilícito de Cannabis se mantienen inalterados como crímenes. Es más, en los tratados internacionales vigentes en Chile, con anterioridad a la modificación del reglamento, el Cannabis ya formaba parte de la lista de aquellas sustancias que causan grave daño a la salud de las personas. No se puede exigir la aplicación del inciso 2 del artículo 1, pues dicha rebaja de pena es facultativa para el juez; porque la conducta típica regulada en el artículo 3 de la Ley $\mathrm{N}^{\circ} 20.000$, no hace ninguna distinción entre drogas o sustancias estupefacientes reguladas en los incisos 1 ó 2 del artículo 1 de la misma ley; y, porque tal rebaja sólo es aplicable a las drogas que se encuentran en lista 2. Por ello, tanto si el juez considera a la Cannabis en la lista 1, como si decide no aplicar el inciso 2 aunque le reconozca su anterior ubicación en lista 2, su decisión no es susceptible de recurso de nulidad alguno.

No puede reclamarse irretroactividad de la ley penal desfavorable, pues no se ha modificado el tipo penal, y la norma de rebaja de pena, de cuya exclusión se reclama, es facultativa, no exigible ni reclamable.

b) Posesión o venta de otra sustancia incorporada en el Listado I, cometida antes de una modificación al reglamento, y juzgada después de aquella, si en la nueva regulación apareciese en Listado II.

En este caso, no existe ningún inconveniente en reconocer la nueva ubicación de una sustancia, en virtud del principio de proporcionalidad, dado que es facultativo del Juez aplicar, en el caso concreto, la rebaja de pena que establece el inciso 2 del artículo 1.

c) Posesión o venta de otra sustancia incorporada en el Listado I, cometida y juzgada antes de una modificación al reglamento, si en la nueva regulación apareciese en Listado II.

Al igual que en el caso anterior, dependiendo del juicio de proporcionalidad que realice el Juez al analizar los hechos de la causa, aquel podrá decidir o no modificar la sentencia.

d) Posesión o venta de una sustancia incorporada en el Listado I o II, cometida antes de una modificación al reglamento, si en la nueva regulación desaparece de sus listados.

En este caso, aplicando la retroactividad de la norma penal más benigna, y siendo el reglamento el límite de la punibilidad, debe considerarse su sanción como innecesaria en atención a su nueva valoración jurídica.

\subsection{Otros casos de modificación de reglamento.}

\subsubsection{Leyes penales en blanco con reenvío total.}

El artículo 318 del C.P. señala la sanción, pero si bien determina el bien jurídico protegido, no indica la forma en que se pone en peligro a la salud pública, no hay verbo rector, ni 
información sobre su faz subjetiva, dejando su especificación al criterio de la autoridad sanitaria. ${ }^{85}$

¿Cuál es el efecto de la modificación del reglamento? En este tipo de delitos, la modificación del reglamento se transforma, en la práctica, en la modificación del delito o en la creación de uno nuevo, quedando sujeta tal decisión al solo criterio de la potestad reglamentaria autónoma. Estas normas no cumplen las exigencias de lex certa y lex scripta. Por este motivo, puede discutirse la constitucionalidad de este delito.

\subsubsection{Leyes penales en blanco con reenvío parcial.}

El artículo 314 del C.P. hace una mejor determinación de la conducta punible (además de dejar claramente establecido el bien jurídico protegido), no quedando a la voluntad de la autoridad administrativa la determinación de ésta. ${ }^{86}$ La conducta consiste en expender (verbo rector) ciertas sustancias, y aquellas tienen la característica de ser peligrosas para la salud y no formar parte de las mencionadas en los artículos anteriores, dejando a la normativa reglamentaria sólo los detalles más técnicos.

Asimismo, el art. 322 del C.P. describe claramente la conducta, a través de los verbos exhumar y trasladar, señalando como su objeto a los restos humanos, sin perjuicio del reenvío a las normas de sanidad que regulan la forma correcta o autorizada de hacer esto ${ }^{87}$ en el caso del art. 288 del C.P., queda meridianamente precisado, a través de los verbos fabricar, vender o distribuir, en qué consiste la conducta sancionada; lo mismo se predica del art. 256 C.P. y del art. 43 de Ley $\mathrm{N}^{\circ} 18.302$ sobre seguridad nuclear. En todos los tipos mencionados aparece el verbo rector de la conducta sancionada y llevan implícita la exigencia de dolo, pues no es factible su comisión imprudente o culposa. El art. 492 del C.P. es un ejemplo de comisión imprudente de este tipo de delitos.

A su vez, en el art. $299 \mathrm{~N}^{\circ} 3$ del Código de Justicia Militar (en adelante, C.J.M.), los deberes militares no son especificados en dicho código, sino que en el Reglamento de disciplina de las FF.AA ${ }^{88}$ Me parece que el reglamento es suficientemente claro, y el verbo incumplir permite entender en qué consiste la conducta típica.

\footnotetext{
${ }^{85}$ ETCHEBERRY, Derecho Penal (parte general), cit. nota no 4, pp. 83 y 84; COUSIÑO, Derecho Penal (parte general), cit. nota $\mathrm{n}^{\mathrm{o}} 30, \mathrm{p} .84$.

${ }^{86}$ Comparte esta opinión, ETCHEBERRY, Derecho Penal (parte general), cit. nota n ${ }^{\circ} 4$, p. 83.

${ }^{87}$ Artículos 135 y ss. del Código Sanitario y Decreto $N^{\circ} 357$, de Salud, de 18-06-1970. En una posición contraria, NOVOA MONREAL, Curso, cit. nota $\mathrm{n}^{\circ} 10$, p. 120, quien estima que en este artículo no se describe con precisión la conducta constitutiva del delito.

${ }^{88}$ Reglamento $\mathrm{N}^{\circ}$ 1445, de 14-12-1951. STC, de 09-11-2006, rol No 468: "la expresión 'deje de cumplir deberes militares' es equivalente a describir el 'núcleo central de la prohibición"”. Para el voto de minoría "Las expresiones 'en ella', no pueden entenderse sino como la exigencia de que sea la ley, y no una norma de inferior jerarquía, la que describa la conducta punible”. STC, de 07-06-2007, rol № 559. SCS, de 16-07-2002, I.C. $N^{\circ}$ 4790-2002: "Dicho precepto efectivamente no describe completa y expresamente la conducta que se sanciona,... define la esencia de la conducta punible, que es infringir por un militar los deberes que le impone su rango y categoría". En posición algo distinta, STC, de 27-09-2007, rol N 781: "los deberes del policía en esta materia no se encuentran contenidos en un decreto supremo reglamentario como el exigido por dicho precepto... la norma impugnada es una ley penal abierta", porque el reglamento policial no es de los indicados en el art. 431 del C.J.M.
} 


\section{Polit. crim., Vol. 4, No 7 (Julio 2009), Art. 4, pp. 125-150 (1-26). \\ [http://www.politicacriminal.cl/Vol_04/n_07/Vol4N7A4.pdf]}

¿Qué ocurre si se modifica el reglamento? La potestad reglamentaria de ejecución debe atenerse a los términos y límites legales, por lo que no puede incorporar nuevas conductas al tipo penal, mas si es posible que ciertas sustancias o ciertas formas de exhumación o cierto tipo de armas, dejen de ser consideradas como peligrosas o prohibidas, provocando la despenalización de las conductas referidas a ellas, cuya aplicación retroactiva por ser más benigna es posible; por el contrario, si la modificación reglamentaria incorporara como prohibidas o peligrosas a ciertas sustancias, formas de exhumación o armas que antes no están consideradas así, ampliando el ámbito del injusto, aquella sólo puede operar hacia el futuro y no retroactivamente.

\subsection{Un caso singular. Modificación de la interpretación del órgano supervisor.}

Nos referimos al interesante caso en que se realice una conducta que hasta ese momento era considerada como lícita por el órgano fiscalizador o regulador; y que, con posterioridad a la ejecución del hecho, pasa a ser considerada por aquel como un delito, en virtud de un cambio en su interpretación de dicha ley. Tal interpretación no es una norma reglamentaria que sirva de complemento a una ley penal en blanco, no puede considerarse como integrante del tipo penal, pero ciertamente tiene influencia en su interpretación, puesto que si una conducta no es considerada ilícita a nivel comercial o administrativo, de manera alguna podría serlo en el ámbito penal.

En los delitos de uso de información privilegiada, regulados en el artículo 85, inciso 1, en relación con artículo 59, letra e), y en el artículo 60, letra e), todos de la Ley $\mathrm{N}^{\circ} 18.045$, si bien no son leyes penales en blanco propias, ${ }^{89}$ las interpretaciones que sobre estas actuaciones hace la Superintendencia de Valores y Seguros son un referente para los actores de dicho mercado.

En el ámbito del derecho penal económico, en que existen órganos reguladores de la actividad que generan una amplia interpretación administrativa de la legislación, la que suele ser de conocimiento de los actores del mercado en cuestión, la solución es reconocer un error de prohibición invencible, pues si el sujeto realiza la conducta teniendo en cuenta la, hasta ese entonces, interpretación y aplicación (usos y formas) de la ley por parte del órgano administrativo supervisor, no ha podido advertir la antijuridicidad de su comportamiento. ${ }^{90}$

\section{Posibilidades de nulidad frente a la decisión del Juez.}

Frente al cambio de lista de la Cannabis en el reglamento de la Ley $\mathrm{N}^{\circ} 20.000$, la decisión judicial sobre su aplicación puede ser susceptible de ser revisada a través del recurso de nulidad, enfrentando las siguientes hipótesis de decisión:

\footnotetext{
${ }^{89}$ En su configuración influyen los elementos normativos regulados en los artículos 164 y siguientes de la misma ley: reenvío interno.

${ }^{90}$ Sobre las posibilidades de error de tipo y error de prohibición, GARCÍA CAVERO, Derecho Penal, cit. nota $\mathrm{n}^{\circ} 15$, pp. 557 a 559 y 646 a 649.
} 
a) Tanto ahora como antes, yo si le aplicaré la rebaja.

¿Puede pedirse la nulidad por el ministerio público? El recurrente, reclamando la causal del artículo 373, letra b), del Código Procesal Penal, ${ }^{91}$ puede sostener que, en derecho público, sólo puede hacerse aquello que está expresamente permitido, todo lo demás está prohibido; y, en el caso en análisis, se excluyó tal facultad respecto del Cannabis, el juez ya no la tiene, y, por ende, ya no puede ejercerla; además, puede indicar que las facultades de valoración de los jueces no se transforman en derechos sustantivos de los imputados, y los jueces no las mantienen una vez que el legislador así lo ha decidido.

La defensa pudiese argumentar irretroactividad de la ley penal desfavorable, argumentación que debe rechazarse puesto que no se modificó el tipo penal, que sanciona el tráfico de drogas de ambos listados, sólo se excluyó una droga de la posibilidad de ejercicio por el Juez de una norma facultativa de rebaja de pena. Por lo demás, el fundamento de la irretroactividad es la seguridad jurídica, y ésta no se ve afectada pues no es posible considerar que se amenaza a las libertades individuales de los sujetos si la pena que arriesga se encuentra inalterada, la rebaja es sólo una posibilidad remota que dependía de la sola voluntad y criterio del juez.

b) Declara que corresponde la rebaja, pero no la aplica porque cree que se lo impide el nuevo reglamento.

¿Puede pedirse la nulidad por la defensa reclamando la causal del artículo 373, letra a), del Código Procesal Penal? El Juez no incurre en vicio susceptible de nulidad, puesto que la nulidad debe recaer o alegarse en función de la decisión adoptada, y en este caso, tal decisión no es susceptible de nulidad porque no se vulneran las garantías constitucionales, ni los derechos reconocidos en los tratados internacionales. ${ }^{92}$ La irretroactividad de la ley penal desfavorable tiene su fundamento en la seguridad jurídica, y esta no se ha visto afectada porque la pena no ha sido modificada de manera alguna. La norma del inciso 2 del artículo 1 de la Ley 20.000 es una norma de rebaja de pena facultativa para el Juez, y como tal el imputado no puede reclamarla como pena esperada, cuya seguridad jurídica se vería afectada por la exclusión de la Cannabis, su pena esperada es la indicada en el inciso 1 del artículo 1 , y aquella se mantiene inalterada.

c) Tanto ahora como antes, yo no le aplicaría la rebaja.

Frente a esta decisión, ¿puede recurrir de nulidad el imputado? No, pues la ley penal no ha sufrido modificación alguna en su contra. La rebaja es facultativa para el Juez, y si bien el imputado podía solicitar su aplicación antes de la modificación, no podía exigirla.

91 HORVITZ LENNON, María Inés; LÓPEZ MASLE, Julián, Derecho Procesal Penal Chileno, t. II, Santiago: Editorial Jurídica de Chile, 2004, p. 427.

${ }_{92}$ HORVITZ LENNON/LÓPEZ MASLE, Julián, Derecho Procesal, cit. nota no 91, pp. 412 y ss. 


\section{Conclusiones}

La Ley penal en blanco debe expresar, con claridad, el verbo rector de la conducta que se encuentra sancionada, y los elementos de la faz subjetiva del tipo, de manera tal que la circunstancia de que exista una remisión a una norma reglamentaria o administrativa para su complemento no la invalide constitucionalmente, dando cumplimiento a las exigencias de lege scripta y lege certa. Debe, además, poder desprenderse cuál es el bien jurídico protegido. Al contrario, la descripción típica de una mera desobediencia de los reglamentos, sin precisar en qué consiste la conducta punible, no cumple los parámetros exigidos para que dicha ley penal en blanco sea válida, y pudiese cuestionarse constitucionalmente.

Por otra parte, de lege ferenda, sería más apropiado político-criminalmente que las normas reglamentarias que sirven de complemento de una ley penal en blanco cumplieran con la utilización de cláusulas de remisión inversa, ${ }^{93}$ de manera tal que en ellas se advirtiera, también, a los ciudadanos que su incumplimiento puede dar lugar a responsabilidad penal, cerrando en esa forma el círculo de la función de advertencia de los tipos penales.

Finalmente, es innegable que la norma complementaria del tipo penal se incorpora a éste y con ello al injusto penal, por lo que sus modificaciones se rigen por el principio constitucional de la irretroactividad de la ley penal, y por su excepción de la ley penal más favorable para el imputado.

\section{BIBLIOGRAFÍA}

ARROYO ZAPATERO, Luis, "Principio de legalidad y reserva de ley en materia penal", Revista Española de Derecho Constitucional, año 3, Nº 8 (1983).

BACIGALUPO, Enrique, Derecho Penal, parte general, Lima: Ara editores, 2004.

BASCUÑÁN RODRÍGUEZ, Antonio, "La Ley Penal", Revista de Derecho de la Universidad Adolfo Ibáñez, $\mathrm{N}^{\circ} 2$ (2005).

Adolfo Ibáñez, $\mathrm{N}^{\circ} 1$ (2004).

, "Ley Penal”, Revista de Derecho de la Universidad

, "La aplicación de la ley penal más favorable", Revista Jurídica de la Universidad de Puerto Rico, vol. 69, № 1 (2000).

BERISTAÍN, Antonio, S.J. La Droga, aspectos penales y criminológicos, Bogotá: ed. Temis, 1986

BLANCO LOZANO, Carlos, "El principio de vigencia en el derecho penal", Revista de Derecho, Criminología y Ciencias Penales, año II, N² 2 (2000).

BUSTOS RAMÍREZ, Juan, Obras Completas. Derecho Penal, parte Especial, t. III, Santiago: ed. Jurídicas de Santiago, $2^{\text {a }}$ ed., 2009.

, Obras Completas, Derecho Penal, parte general, t. I, Santiago: ed. Jurídica de Santiago, 2007.

, Manual de Derecho Penal, parte general, Barcelona: $4^{\mathrm{a}}$ ed.,

1994.

93 Ejemplos: artículo 35 del Decreto $\mathrm{N}^{\circ}$ 405, de Salud, de 20-02-1984, Reglamento de Productos Psicotrópicos, y artículo 36 del Decreto N 404, de Salud, de 20-02-1984, Reglamento de Estupefacientes. 
, Manual de Derecho Penal, Barcelona: ed. Ariel S.A., $3^{\mathrm{a}}$ ed.,

1989.

CASSOLA PERENZUTTI, Gustavo, Medio ambiente y Derecho Penal, MontevideoBuenos Aires: ed. BdeF, 2005.

CEA EGAÑA, José Luis, Tratado de la Constitución de 1980, Santiago: Editorial Jurídica de Chile, 1988

CERDA SAN MARTÍN, Rodrigo; HERMOSILLA IRIARTE, Francisco, Código Penal, jurisprudencia en el nuevo sistema de justicia criminal, Santiago: Librotecnia, $3^{\mathrm{a}}$ ed., 2008.

CEREZO MIR, José, Derecho Penal, parte general, Montevideo/Buenos Aíres: ed. BdeF Ltda., 2008.

, Curso de Derecho Penal Español, parte general, t. II, Madrid: ed. Tecnos, $5^{\mathrm{a}}$ ed., 1997.

COBO DEL ROSAL, Manuel, "Consideraciones generales sobre el denominado 'tráfico ilegal de drogas tóxicas o estupefacientes"”, en Drogodependencias. Actas del IX Congreso Internacional, Madrid, 1980.

COUSIÑO, Luis, Derecho Penal Chileno, parte general, t. I, Santiago: Editorial Jurídica de Chile, 1975.

CURY URZÚA, Enrique, Derecho Penal, parte general, Santiago: ed. Universidad Católica de Chile, $7^{\mathrm{a}}$ ed., 2005.

, La ley penal en blanco, Bogotá: ed. Temis S.A., 1988.

DE LUCA, Javier Augusto, Leyes penales más benignas, en blanco y Constitución Nacional, Buenos Aires: ed. Ad-Hoc, 1997.

DÍEZ RIPOLLÉS, José Luis, Los delitos relativos a drogas tóxicas, estupefacientes y sustancias psicotrópicas, Madrid: ed. Tecnos, 1989.

ETCHEBERRY, Alfredo, Derecho Penal, parte general, t. I, Santiago: Editorial Jurídica de Chile, $3^{\text {a }}$ ed., 1998.

Muñoz Vera ed.

EVANS DE LA CUADRA, Enrique, Los Derechos Constitucionales, t. II, Santiago: Editorial Jurídica de Chile, $3^{\text {a }}$ ed., 2004.

FERNÁNDEZ CRUZ, José Ángel, "La naturaleza y contenido del mandato de Lex Certa en la doctrina del Tribunal Constitucional Español”, Revista de Derecho, 'Derecho y Medioambiente', número especial (1998).

GARCÍA CAVERO, Percy, Derecho Penal Económico, parte general, t. I, Lima: ed. Jurídicas Grijley, $2^{\mathrm{a}}$ ed., 2007.

GARRIDO MONTT, Mario, Derecho Penal, parte general, t. I, Santiago: Editorial Jurídica de Chile, $1^{\text {a }}$ ed., 1997.

GUZMÁN DÁLBORA, José Luis, "Relaciones del derecho penal con el derecho constitucional, y su concreción en la Constitución Política Chilena (1980)”, Anuario de Filosofía Jurídica y Social, $\mathrm{N}^{\circ} 12$ (1994).

HORVITZ LENNON, María Inés; LÓPEZ MASLE, Julián, Derecho Procesal Penal Chileno, t. II, Santiago: Editorial Jurídica de Chile, 2004.

JAÉN VALLEJO, Manuel, Cuestiones actuales del Derecho Penal económico, Buenos Aires: ed. Ad-Hoc, 2004. 
JAKOBS, Günther, Derecho Penal, parte general. Fundamentos y teoría de la imputación. Trad. CUELLO CONTRERAS, Joaquín; SERRANO GONZÁLEZ DE MURILLO, José Luis, Madrid: Marcial Pons, ediciones jurídicas, 2ª ed. corregida, 1997.

JIMÉNEZ DE ASÚA, Luis, Principios de Derecho Penal. La ley y el delito, Buenos Aires: Abeledo-Perrot, ed. Sudamericanas, 1990.

LUZÓN PEÑA, Diego, Curso de Derecho Penal, parte general, Madrid: ed. Universitas, 2002.

MATUS ACUÑA, Jean Pierre, "Dos problemas de aplicación retroactiva de la ley penal favorable", Revista de Derecho Penal, № 19 (2006).

, "El tráfico ilícito de estupefacientes, en sentido amplio, como figura básica en los delitos de la ley N 19.366”, en: POLITOFF L., Sergio; MATUS A., Jean Pierre (Coords.), Tratamiento Penal del Tráfico Ilícito de Estupefacientes. Estudios de dogmática y jurisprudencia, Santiago: ed. Lexis Nexis, 1998.

Congreso, 1994

, La Ley Penal y su interpretación, Santiago: ed. Jurídicas

MESTRE DELGADO, Esteban, "Límites constitucionales de las remisiones normativas en materia penal", Anuario de Derecho Penal y Ciencias Penales, t. XLI, fascículo II, (1998).

MIR PUIG, Santiago, Derecho Penal, parte general. Montevideo/Buenos Aires: ed. BdeF, $7^{\mathrm{a}}$ ed., 2005.

Introducción a las bases del derecho penal, Montevideo/Buenos Aires: ed. BdeF, $2^{\text {a }}$ ed., 2003.

MUÑOZ CONDE, Francisco, Introducción al Derecho Penal, Montevideo/Buenos Aires: ed. BdeF, 2007. , Derecho Penal, parte especial, Valencia: ed. Tirant Lo Blanch, 1995.

MUÑOZ CONDE, Francisco; GARCÍA ARÁN, Mercedes, Derecho Penal, parte general, Valencia: ed. Tirant Lo Blanch, $7^{\mathrm{a}}$ ed., 2002.

NOVOA MONREAL, Eduardo, Curso de Derecho Penal Chileno, Santiago: Editorial Jurídica de Chile, 1966.

OLIVER CALDERÓN, Guillermo, Retroactividad e irretroactividad de las leyes penales, Santiago: Editorial Jurídica de Chile, 2007.

OLIVER CALDERÓN, Guillermo, "El fundamento del principio de irretroactividad de la ley penal", Revista de Derecho de la Universidad Católica de Valparaíso, XXI (2000).

PÉREZ LUÑO, Antonio, La Seguridad Jurídica, Barcelona: ed. Ariel, 1991.

POLITOFF, Sergio; MATUS, Jean Pierre; RAMÍREZ, María Cecilia, Lecciones de Derecho Penal Chileno, parte general, Santiago: Editorial Jurídica de Chile, $2^{\mathrm{a}}$ ed., 2004.

POLITOFF, Sergio; MATUS Jean Pierre, “Comentario preliminar al art. 18. Aplicación temporal de la Ley Penal", en POLITOFF, Sergio; ORTIZ, Luis (Dir.); MATUS, Jean Pierre (Coord.), Texto y comentario del Código Penal Chileno, t. I, Santiago: Editorial Jurídica de Chile, 2002.

REY HUIDOBRO, Luis Fernando, El delito de tráfico de drogas. Aspectos procesales y penales, Valencia: ed. Tirant lo Blanch, 1999. 
RODRÍGUEZ COLLAO, Luis, "Sobre el papel de la jurisprudencia en la generación del derecho penal", Revista de Derecho, Universidad Católica de la Santísima Concepción, vol. VI, N 6 (1998)

, "Constitucionalidad de las leyes penales en blanco", Revista de Derecho de la Universidad Católica de Valparaíso, VIII (1984).

ROXIN, Claus, Derecho Penal, parte general, t. I. Fundamentos. La estructura de la teoría del delito, Trad. LUZÓN PEÑA, Diego-Manuel; DÍAZ Y GARCÍA CONLLEDO, Miguel; de VICENTE REMESAL, Javier, Madrid: Civitas ediciones, 2006.

SANTANA VEGA, Dulce María, El concepto de ley penal en blanco, Buenos Aires: ed. Ad-Hoc S.R.L., 2000.

SEQUEROS SAZATORNIL, Fernando, El tráfico de drogas ante el ordenamiento jurídico, Madrid: ed. La Ley.

SILVA BASCUÑÁN, Alejandro, Tratado de Derecho Constitucional, t. XI, Santiago: Editorial Jurídica de Chile, $2^{\mathrm{a}}$ ed., 2006.

SILVA SÁNCHEZ, Jesús María, Aproximación al Derecho Penal Contemporáneo, Barcelona: ed. Bosch, 2002.

"Legislación penal socio-económica y retroactividad de disposiciones favorables: el caso de las «leyes en blanco»", en: Hacia un derecho penal económico europeo, jornadas en honor del profesor Klaus Tiedemann, Madrid: Boletín Oficial del Estado, Estudios Jurídicos, Serie Derecho Público, 1995.

TIEDEMANN, Klaus, "La ley penal en blanco: concepto y cuestiones conexas", trad. LLABRÉS FUSTER, Antoni, en: EL MISMO, Temas de Derecho Penal Económico y Ambiental, Lima: ed. Idemsa, 1999.

VERDUGO MARINKOVIC, Mario, Código Penal, t. I, Santiago: ed. Jurídicas EdiarConosur Ltda., $2^{\mathrm{a}}$ ed., 1986.

YÁÑEZ PÉREZ, Sergio, “Las leyes penales en blanco”, Gaceta Jurídica, № 58 (1985). 